\title{
Exon Mutation
}

National Cancer Institute

\section{Source}

National Cancer Institute. Exon Mutation. NCI Thesaurus. Code C148639.

A change in the nucleotide sequence of an exon in a gene. 